INFLATION, SAVING AND GROWTH IN DEVELOPING EGONOMIES 
By the same author

Growth and Development with Special Reference to Developing Economies 


\title{
INFLATION, SAVING AND GROWTH IN DEVELOPING EGONOMIES
}

\author{
A. P. THIRLWALL \\ Reader in Economics, University of Kent
}

Macmillan Education 
(C) A. P. Thirlwall 1974

Softcover reprint of the hardcover 1st edition 1974 978-0-333-15107-5

All rights reserved. No part of this publication may be reproduced or transmitted, in any form or by any means, without permission.

First published 1974 by

THE MACMILLAN PRESS LTD

London and Basingstoke

Associated companies in New York Dublin

Melbourne Johannesburg and Madras

ISBN 978-0-333-17310-7 ISBN 978-1-349-86179-8 (eBook)

DOI 10.1007/978-1-349-86179-8

Text set in 10/12 pt Monotype Baskerville

The paperback edition of this book is sold subject to the condition that it shall not, by way of trade or otherwise, be lent, re-sold, hired out, or otherwise circulated without the publisher's prior consent in any form of binding or cover other than that in which it is published and without a similar condition including this condition being imposed on the subsequent purchaser. 
To Lorenzo and Alessandra and their generation 


\section{Contents}

PrefaGe $\quad x i$

1 Inflation, Saving and Growth 1

Introduction 1

The Growth of Output and Living Standards 4

Capital Accumulation $\quad 5$

Growth and the Savings Ratio $\quad 8$

The Role of Inflationary Finance $\quad 12$

2 The Gase For and Against Inflationary $\begin{array}{ll}\text { FinANGE } & 18\end{array}$

The Doctrine of Forced Saving $\quad 18$

The Keynesian and Quantity Theory Approaches to Inflationary Finance $\quad 22$

The Dangers of Inflation $\quad 30$

The Inflationary Experience $\quad 34$

3 TyPES OF INFLATION 37

Pure Demand Models 38

Pure Cost Models $\quad 44$

Hybrid Models $\quad 46$

Structural Models of Inflation $\quad 51$

Expectations Models $\quad 55$

$\begin{array}{ll}\text { Conclusion } & 60\end{array}$

4 Models of the EfFects of Inflation on

Saving and Growth 64

Harrod's Model of Growth 64

The Natural Rate of Growth 68

The Classical Model $\quad 72$

Neo-Classical Growth Theory $\quad 74$

Neo-Classical Monetary Growth Theory $\quad 78$ 
viii GONTENTS

Forced Saving $\quad 86$

Mrs Robinson's Model $\quad 89$

Kaldor's Model $\quad 92$

Kalecki's Model 94

Inflation and the Real Interest Rate $\quad 96$

Reconciling the Prior Saving versus Forced Saving Approaches to Development $\quad 98$

5 Money in a Developing Egonomy 101

Money and Development 104

The Role of Banks 111

Development Banks $\quad 115$

The Unorganised Money Market 117

Empirical Evidence on the Relation Between Money and Growth 119

6 Raising the Warranted Rate of Growth 122

The Redistribution Effects of Inflation on Saving 122

A Two-Sector Model of the Effect on Saving of Income

Redistribution between Wages and Profits

The Redistribution of Real Income to Government: Inflation as a Tax on Money

Non-Inflationary Finance of Investment 132

Mundell's Model of Credit-Financed Growth 134

Reducing the Capital-Output Ratio $\quad 140$

Investment, the Capital-Output Ratio and the Multiplier $\quad 141$

Changing the Structure of Investment 144

Under-utilisation of Capital $\quad 145$

Altering the Capital Intensity of Techniques 148

Empirical Evidence on the Capital-Output Ratio 156

7 Per Capita Income, the Growth of Income and the Savings Ratio

Per Capita Income and the Savings Ratio 161

The Life-Cycle Hypothesis of Saving 170

8 Inflation, Saving and Growth in the Open EGONOMY

Inflation and the Balance of Payments 178

The Import Surplus, Saving and Growth 186 
9 Inflation and Growth: The Empirical EVIDENGE

Inflation and the Savings Ratio

Appendix 1 Data on Savings, Investment, Per Capita Income, Growth and INFLATION

Appendix 2 Regression Results of the Relation BETWEEN Saving and INFLATION And Investment and Inflation 239 


\section{Preface}

The purpose of this book is to consider the theory and empirical evidence, such as it is, in support of the view that inflationary finance, and the process of inflation itself, can, within limits, accelerate the development process so that countries may achieve tolerable living standards, as measured by real per capita income, sooner than would otherwise be the case. It redresses the bias against inflationary finance found in most traditional textbooks. The book is not intended to be a tight theoretical exposition of money and inflation in growth models. It is intended as a contribution to the development debate, presenting in general terms, with occasional theoretical backing, a case for more expansionary policies in developing economies which may involve inflation. The term inflation is used here in the formal sense of a rise in the general price level whatever its cause; on the other hand, particular attention will be centred on the term in its traditional sense of governments using monetary means to finance expenditure. Strictly speaking, monetary expansion need not necessarily involve a rise in the price level if supply can match increases in monetary demand, but in situations where capital and consumer goods are in short supply it normally will - at least in the short run. There is also a distinction to be made between demand inflation and other types of inflation. The argument for inflation is essentially an argument for demand inflation. Other types of inflation, including cost inflation and structural inflation, are best considered as the price of growth rather than a stimulus.

This is not a subject which has received systematic treatment in the development literature at a level appropriate for undergraduate students. Yet the subject is important because of the issues it raises for development strategy which at some stage must be faced by the economist and policy maker alike. What is the most appropriate rate of monetary expansion? What is the 'optimum' rate of inflation? What proportion of investment resources should be bid away by governments to enable them to invest resources more 'profitably' on society's behalf? These are not questions that can be lightly pushed 
aside. They must be considered alongside tax policy, choice of technology, foreign trade policy, and so on.

As will become clear throughout the course of the book the case for inflationary policies, leading to rising prices, which some people might call the Keynesian approach to development, is not clear cut theoretically, and the empirical evidence is equivocal. From studying the inflationary experience of the developing countries outside Latin America, however, it is difficult not to be struck by the apparent caution and conservatism that seems to have prevailed in the majority of countries, at least until the recent past. To some extent this can be seen from the statistics on inflation for these countries, which show for most of the post-war period rates of inflation averaging not more than 3 to 4 per cent per year. Admittedly some of the sting of excess monetary demand is typically taken out of the developing economies by imports, and inflation rates may also be under-recorded for obvious political reasons, but the impression remains that capital accumulation and employment growth may have been sacrificed for the sake of financial stability. With these background observations in mind the book is written with a bias in favour of more expansionist government policies.

It is only fair to warn the reader in advance, however, that the empirical evidence to support the assertion that inflation is strongly conducive to higher rates of per capita income growth is hard to come by. The results in Chapter 9, which examine the relation between inflation and the savings ratio, are very disappointing. As we remarked earlier, however, there is a distinction to be made between inflationary finance and the process of inflation, and also between types of inflation, some of which are conducive to growth and others not. In a way, the more 'successful' inflationary finance is in financing projects which raise output, the weaker the relation between output growth and rising prices is likely to be. Unfortunately the relation between demand expansion and growth is not directly observable. Only the relation between price rises and growth is directly observable. Furthermore, it is impossible to say how much observed inflation is attributable to one cause or another. The relation between demand inflation and growth could easily be distorted by varying degrees of other types of inflation. These difficulties should be borne in mind in interpreting and evaluating the empirical results, especially in Chapter 9.

The book turns out to be a cross between a textbook and a mild 
polemic. Textbooks and polemics are not always comfortable bedfellows. If this book suffers as a result, I apologise in advance. I am hopeful, however, that the general argument, the theoretical exposition and the mixture of old and new empirical evidence will be of interest and use to students in the sense of providing a systematic treatment of a relatively neglected topic in traditional textbooks (including my own! ${ }^{1}$ ).

The polemical side of the book I am less sanguine about. It takes a particular view of the development process that many people may react against. In particular, there is heavy emphasis on the role of capital accumulation in the development process; on the role and responsibility of governments in promoting development, and on the necessity to invest in excess of plans to save to forcibly release resources for the development effort. The stress on combining inflationary policies with the development of the agricultural sector, however, and on changing factor proportions in favour of more labour intensive techniques, will I hope meet with wide support.

I am conscious, of course, that since embarking on this book, inflation in almost every country in the world has become a common fact of life. Events have caught up with me, so to speak! I am not so alarmed by this occurrence as some of my colleagues. Indeed, I take the recent bout of inflation as support for the polemical position taken. It coincides with unprecedented rates of growth of output in the greater part of the world economy.

The book was embarked on while I was Research Associate in the Industrial Relations Section, Princeton University, 1971-2. I shall be eternally grateful to the Section for its hospitality and support, not to mention the constant stimulus of my colleagues, especially Orley Ashenfelter, Dan Hamermesh, Jim Hefner, Al Rees and my research assistant, Hal White. The book was completed at the University of Kent. My colleagues Bob Dixon (now at the University of Papua New Guinea), Roger Hill, Homa Katouzian and Charles Kennedy all read the complete manuscript, and I am deeply grateful for their constructive criticisms and advice for improvement even though it has not always been heeded. My secretary, Marilyn Spice, typed successive drafts of the book. To her, for the help and understanding over the years, I am also deeply grateful.

${ }^{1}$ Growth and Development with Special Reference to Developing Economies (London: Macmillan, 1972). 
'It is worse, in an impoverished world, to provoke unemployment than to disappoint the rentier.'

J. M. Keynes

'Inflation which is due to the creation of money for the purpose of accelerating capital formation results in accelerated capital formation.' A. Lewis 